\title{
Peningkatan Aktivitas dan Hasil Belajar PKN Melalui Metode Pembelajaran Student Teams Achievment Divisions (STAD) Pada Siswa Kelas V SD Negeri 2 Sengonwetan Semester 2 Tahun Pelajaran 2016/2017
}

\author{
Suwito \\ suwitosengon2@gmail.com \\ SD Negeri 2 Sengonwetan \\ UPTD Pendidikan Kecamatan Kradenan Kabupaten Grobogan
}

\begin{abstract}
Abstrak
Penelitian ini bertujuan untuk mendeskripsikan Melalui Metode Pembelajaran Student Teams Achievment Divisions (STAD) dapat meningkatkan aktivitas dan hasil belajar siswa Kelas V SD Negeri 2 Sengonwetan semester 2 Tahun Pelajaran 2016 / 2017. Siklus ini dilakukan di SD Negeri 2 Sengonwetan. Peningkatan Aktivitas dan Hasil Belajar PKN melalui Metode Pembelajaran Student Teams Achievment Divisions (STAD) pada Siswa Kelas V SD Negeri 2 Sengonwetan Semester 2 Tahun Pelajaran 2016 / 2017 dilaksanakan dari bulan Januari sampai bulan April 2017. Subjek perbaikan di sekolah ini adalah siswa kelas V di SD Negeri 2 Sengonwetan Kecamatan dengan jumlah 25 siswa. Tindakan diadakan sebanyak 2 kali. Masing - masing terdiri dari 4 tahap yaitu: Tahap perencanaan, tahap pelaksanaan, tahap observasi, dan tahap refleksi. Hasil belajar siswa pada pembelajaran PKN dengan metode pembelajaran Student Teams Achievment Divisions (STAD) mengalami peningkatan pada setiap siklus. Hal itu dapat dilihat dari persentase ketuntasan kondisi awal $48 \%$, meningkat menjadi $72 \%$ pada Siklus I. Kemudian setelah dilakukan perbaikan, pada Siklus II persentase ketuntasan kembali meningkat menjadi $96 \%$ dan telah memenuhi indikator keberhasilan yaitu sekurang-kurangnya $80 \%$. Aktivitas siswa pada Siklus ini mengalami peningkatan. Pada Siklus I data hasil pengamatan siswa mendapatkan skor rata-rata 10 dengan kategori cukup. Pada Siklus II aktivitas siswa meningkat dengan perolehan skor 13 dengan kategori baik. Dengan demikian dapat disimpulkan bahwa pemerolehan skor aktivitas siswa sudah memenuhi indikator keberhasilan kategori baik (11-15). Dari hasil Siklus di atas, dapat disimpulkan bahwa melalui Metode Pembelajaran Student Teams Achievment Divisions (STAD) Dapat Meningkatkan Aktivitas dan Hasil Belajar PKN pada Siswa Kelas V SD Negeri 2 Sengonwetan Semester 2 Tahun Pelajaran 2016 / 2017 secara signifikan.
\end{abstract}

Kata kunci: Aktivitas, Hasil belajar PKN, Metode Pembelajaran Student Teams Achievment Divisions (STAD).

\section{PENDAHULUAN}

Undang-Undang Nomor 20 tahun 2003 tentang Sistem Pendidikan Nasional, pasal 3 (Depdiknas, 2003) menyebutkan bahwa, "Pendidikan berfungsi mengembangkan kemampuan dan membentuk watak serta peradaban bangsa yang bermartabat dalam rangka mencerdaskan kehidupan bangsa, bertujuan untuk berkembangnya potensi peserta didik agar menjadi manusia yang beriman dan bertaqwa kepada Tuhan Yang Maha Esa, berakhlak mulia, sehat, berilmu, cakap, kreatif, mandiri dan menjadi warga negara yang demokratis serta tanggung jawab". Berdasarkan fungsi Pendidikan Nasional di atas maka peran guru menjadi kunci keberhasilan dalam pembelajaran di sekolah dan 
bertanggung jawab untuk mengatur, mengarahkan dan menciptakan suasana kondusif yang mendorong siswa untuk meleksanakan kegiatan di kelas.

Tujuan mata pelajaran PKN di SD atau MI ialah agar peserta didik memiliki kemampuan memperoleh keyakinan terhadap kebesaran Tuhan Yang Maha Esa berdasarkan keberadaan, keindahan dan keteraturan alam ciptaan-Nya, mengembangkan pengetahuan dan pemahaman konsepkonsep PKN yang bermanfaat dan dapat diterapkan dalam kehidupan sehari-hari; mengembangkan rasa ingin tahu, sikap positif dan kesadaran tentang adanyan hubungan yang saling mempengaruhi antara PKN, lingkungan, teknologi dan masyarakat; mengembangkan keterampilan proses untuk menyelidiki alam sekitar, memecahkan masalah dan membuat keputusan; meningkatkan kesadaran untuk menghargai alam dan segala keteraturannya sebagai salah satu ciptaan Tuhan; dan memperoleh bekal pengetahuan, konsep dan keterampilan PKN sebagai dasar untuk melanjutkan pendidikan ke SMP atau MTs (Al et al., 2017).

Pembelajaran merupakan cara yang dilakukan guru dalam menjalankan fungsinya merupakan alat mencapai tujuan pembelajaran (Uno, 2010). Sedangkan berdasarkan temuan (Depdiknas, 2007), dari hasil penelitian tersebut menunjukkan bahwa masih banyak permasalahan pelaksanaan standar isi mata pelajaran PKN, Guru dalam menerapkan pembelajaran lebih menekankan pada metode yang mengaktifkan guru, pembelajaran yang dilakukan guru kurang kreatif, lebih banyak menggunakan metode ceramah dan kurang mengoptimalkan media pembelajaran. Sehingga siswa kurang kreatif dalam pembelajaran

Berdasarkan temuan (Depdiknas, 2007), dari hasil penelitian tersebut menunjukkan bahwa masih banyak permasalahan pelaksanaan standar isi mata pelajaran PKN. Guru dalam menerapkan pembelajaran lebih menekankan pada metode yang mengaktifkan guru, pembelajaran yang dilakukan guru kurang kreatif, lebih banyak menggunakan metode ceramah dan kurang mengoptimalkan media pembelajaran. Sehingga siswa kurang kreatif dalam pembelajaran

Hal tersebut juga dijumpai di SD Negeri 2 Sengonwetan,Kecamatan Kradenan. Berdasarkan hasil observasi pada semester 2 awal tahun pelajaran 2016 / 2017, dalam melaksanakan proses Mata pelajaran PKn siswa sulit memahami materi yang ada. Kendala yang terjadi adalah siswa merasa bosan, siswa tidak berminat mengikuti Mata pelajaran PKn . Hal ini terjadi karena guru kurang kreatif dalam menyelenggarakan pembelajaran, guru hanya menggunakan metode konvensional tanpa menggunakan media ataupun alat peraga, pembelajaran bersifat satu arah yaitu dari guru ke siswa,tidak ada interaksi antara guru dan siswa dan monoton. Disini guru tidak menggunakan metode pembelajaran yang tepat dan sumber belajar yang jauh dari kata memadai. Dan hasil belajar siswa pada mata pelajaran $\mathrm{PKN}$ sangat rendah.

Dari hasil observasi pada siswa Kelas V SD Negeri 2 Sengonwetan Kecamatan Kradenan hasil nilai ulangan harian tergolong rendah, ditunjukkan dengan data, dari 23 siswa hanya 11 siswa (48 $\%$ ) yang mendapatkan nilai diatas Kriteria Ketuntasan Minimal (KKM) yaitu 70,sedangkan sisanya 12 siswa (52 \%) nilainya dibawah KKM. Ditambah dengan hasil wawancara pada siswa didapat hasil bahwa ,masih banyak siswa yang tidak memahami materi PKN.

Hasil belajar PKn siswa yang sangat rendah merupakan permasalahan yang sangat serius dan harus segera diatasi. Proses belajar PKN harusnya berlangsung mengasyikan dan dalam suasana gembira, sehingga jalan masuk untuk ilmu pemgetahuan akan terbuka lebar dan tersimpan dengan baik. Tentunya guru mempunyai peran besar dalam menyelenggarakan suasana belajar, karena guru adalah ujung tombak dalam pembelajaran, guru harus menggunakan media yang sesuai , memilih metode yang tepat dalam memecahkan masalah belajar pada siswa. Guru juga harus mampu mencapai tujuan pembelajaran sehingga hasil belajar PKn pada siswa akan meningkat dan mencapai ketuntasan KKM.

Berdasarkan analisis masalah yang telah dilakukan, peneliti menetapkan alternatif tindakan yang tepat untuk meningkatkan kualaitas pembelajaran yang dapat mendorong keaktifan siswa dalam 
Mata pelajaran PKN. Alternatif tindakan yang dipilih adalah dengan penerapan STAD (Student TeamsAchievement Divisions)(Permana, 2016).

Bertolak dari permasalahan di atas, maka peneliti mencoba untuk mengkaji tentang upaya apa yang harus dilakukan untuk meningkatkan aktivitas dan hasil belajar PKn melalui penelitian tindakan kelas dengan judul "Peningkatan Aktivitas dan Hasil Belajar PKN melalui Metode Pembelajaran Student Teams Achievment Divisions (STAD) pada Siswa Kelas V SD Negeri 2 Sengonwetan Semester 2 Tahun Pelajaran 2016 / 2017".

\section{METODE PENELITIAN}

Penelitian dilaksanakan pada semester 2 tahun pelajaran 2016 / 2017. Proses pengumpulan data, pengolahan data-data, analisis data, pengambilan simpulan, dan penyusunan laporan penelitian membutuhkan waktu selama 4 bulan, yaitu pada bulan Januari sampai dengan April 2017. Penelitian dilakukan di Kelas V Semester 2 SD Negeri 2 Sengonwetan Kecamatan Kradenan Kabupaten Grobogan Tahun 2016 / 2017, karena tugas dilakukan sesuai dengan surat tugas mengajar dan mendapat tugas tambahan menjadi Kepala Sekolah pada Semester 2 Tahun 2016 / 2017. Pada penelitian ini yang dijadikan subjek penelitian adalah guru dan seluruh siswa Kelas V SD Negeri 2 Sengonwetan yang berjumlah 25 siswa. Terdiri dari 9 siswa laki-laki dan 16 siswa perempuan. Sumber data siswa diperoleh dari hasil observasi yang diperoleh secara sistematik selama pelaksanaan siklus pertama sampai dengan siklus kedua, hasil evaluasi, dan hasil wawancara siswa Kelas V SD Negeri 2 Sengonwetan, Kecamatan Kradenan, Kabupaten Grobogan.

Rancangan dalam penelitian ini adalah penelitian tindakan kelas,langkah-langkah penelitian tindakan kelas dibagi menjadi empat kegiatan, yaitu perencanaan, tindakan, pengamatan/observasi, dan refleksi (Arikunto, 2010). Berikut disajikan gambar siklus PTK.

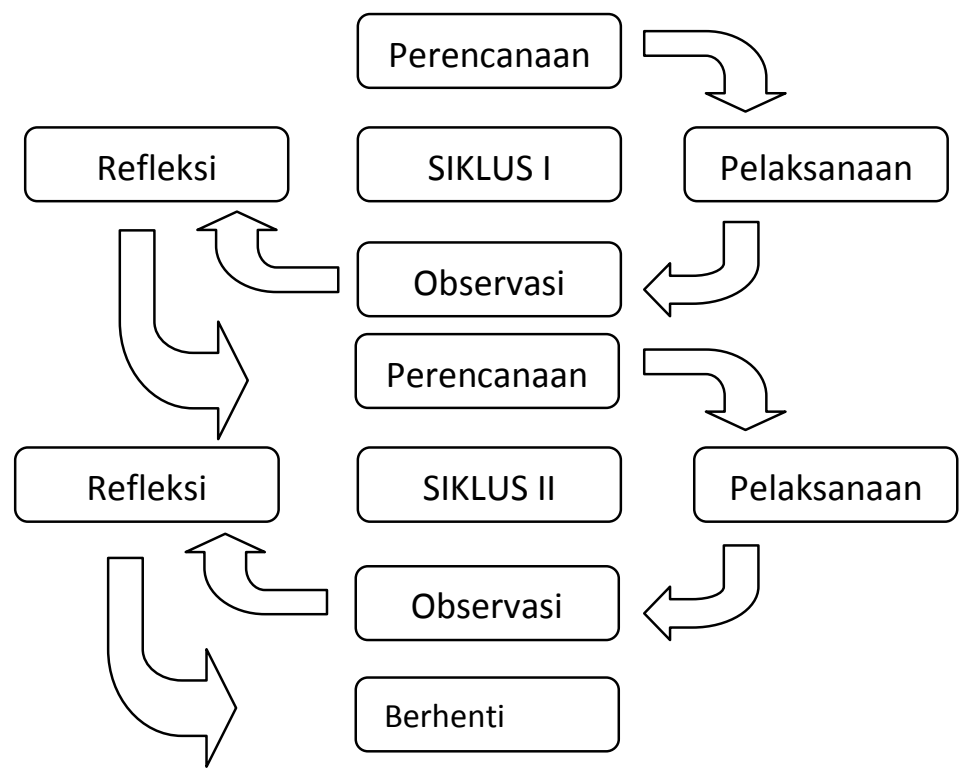

Gambar 1. Siklus Penelitian Tindakan Kelas (Arikunto, 2010)

\section{HASIL DAN PEMBAHASAN}

Data observasi Prasiklus menyatakan bahwa sebelum dilakukan tindakan, Mata pelajaran PKN di SD Negeri 2 Sengonwetan berjalan kurang efektif. Hal-hal yang menyebabkan Mata pelajaran PKN kurang efektif antara lain, dalam melaksanakan proses Mata pelajaran PKN siswa sulit memahami materi yang ada. Kendala yang terjadi adalah siswa merasa bosan, siswa tidak berminat mengikuti Mata pelajaran PKN Hal ini terjadi karena guru kurang kreatif dalam menyelenggarakan pembelajaran, guru hanya menggunakan metode konvensional tanpa menggunakan media ataupun alat peraga, 
pembelajaran bersifat satu arah yaitu dari guru ke siswa,tidak ada interaksi antara guru dan siswa dan monoton. Disini guru tidak menggunakan metode pembelajaran yang tepat dan sumber belajar yang jauh dari kata memadai. Dan hasil belajar siswa pada mata pelajaran PKN sangat rendah.

Dari hasil observasi pada siswa Kelas V SD Negeri 2 Sengonwetan Kecamatan Kradenan hasil nilai ulangan harian tergolong rendah, ditunjukkan dengan data, dari 25 siswa hanya 12 siswa (48\%) yang mendapatkan nilai di atas Kriteria Ketuntasan Minimal (KKM) yaitu 70, sedangkan sisanya 13 siswa (52\%) nilainya dibawah KKM. Ditambah dengan hasil wawancara pada siswa didapatkan hasil bahwa masih banyak siswa yang kurang memahami materi PKN.

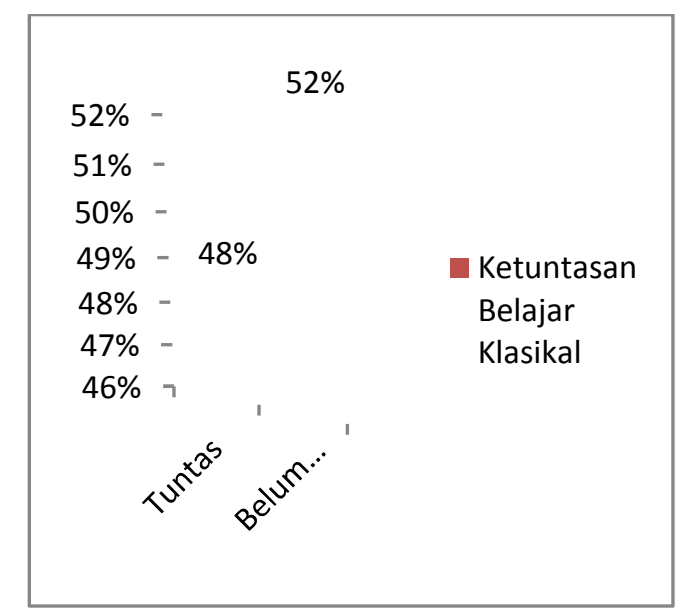

Gambar 2. Presentase Ketuntasan Belajar Klasikal Pada Prasiklus

Sebelum melaksanakan tindakan, peneliti membuat berbagai perencanaan yaitu Peneliti menyiapkan rencana pelaksanaan Mata pelajaran PKN Kelas V dengan Standar Kompetensi 3. Memahami kebebasan berorganisasi. Kompetensi Dasar 3.1 Mendeskripsikan pengertian organisasi, Mempersiapkan sumber dan media pembelajaran berupa buku paket PKN, alat tulis, serta media, Mempersiapkan alat evaluasi berupa tes tertulis atau lembar soal dan lembar kerja siswa (LKS), Membuat lembar pengamatan untuk guru dalam melaksanakan pembelajaran. Membuat lembar pengamatan aktivitas siswa dalam mengikuti kegiatan pembelajaran.

Pelaksanaan tindakan siklus I pada hari Selasa, 7 dan 14 Februari 2017. Berdasarkan data hasil pelaksanaan pembelajaran siklus I, didapatkan bahwa hasil belajar siswa mengalami peningkatan jika dibandingkan dengan data awal atau Prasiklus. Hal itu dapat dibuktikan dengan data tabel dan diagram sebagai berikut.

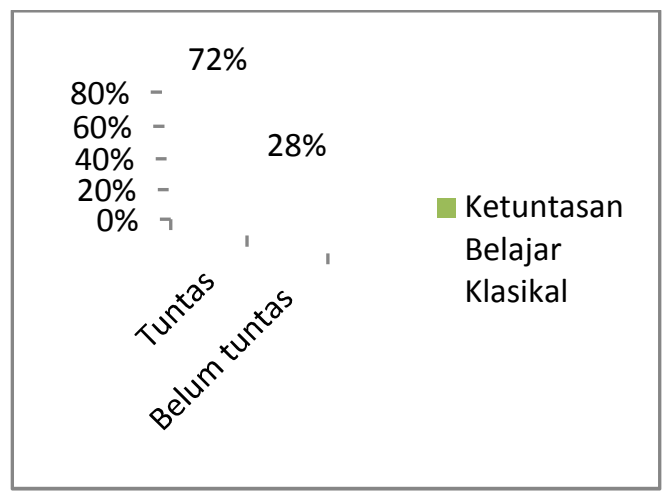

Gambar 3. Presentase Ketuntasan Belajar Klasikal Siklus I

Hasil observasi berupa pengamatan terhadap aktivitas siswa antara lain: Kesiapan dan semangat siswa mengikuti proses pembelajaran (Emotional activities), Menanggapi apersepsi (Mental 
activities), Memperhatikan informasi yang disampaikan guru (Listening activities,Visual activities), Ketertiban pada saat pembentukan kelompok (Emotional activities), Mendiskusikan lembar pertanyaan yang diberikan guru (Mental activities, Motor activities, Writing activities), Kerjasama dalam kelompok.(Mental activities, Motor activities, Writing), Melaporkan hasil diskusi kelompok.(Oral activities), Ketertiban siswa ketika mendapatkan penghargaan dari guru (Emotional activities), Membuat kesimpulan diskusi/ pembelajaran bersama guru (Oral activities)(Hamdu, 2011).

Pada pelaksanaan tindakan siklus I yaitu pada Mata pelajaran PKN melalui Metode Pembelajaran Student Teams Achievment Divisions pada Kelas V SD Negeri 2 Sengonwetan didapatkan data bahwa nilai rata-rata aktivitas belajar siswa adalah 10 kategori cukup terdiri dari siswa yang memperoleh nilai kategori cukup ada 11 siswa dengan presentase $44 \%$, siswa yang memperoleh nilai kategori baik ada 13 siswa dengan presentase $52 \%$,siswa yang memperoleh nilai kategori amat baik ada 1 siswa dengan presentase $4 \%$. Jadi presentase siswa yang memperoleh nilai tuntas pada siklus I $56 \%$.

Berdasarkan paparan di atas dapat diketahui bahwa aktivitas siswa pada siklus I belum dapat terpenuhi secara maksimal.Hal ini disebabkan karena siswa belum terbiasa melakukan diskusi sehingga guru masih kesusahan dalam mengatur kelompok.Keberanian siswa dalam menyampaikan hasil diskusi juga masih kurang.Masih banyak siswa yang malu-malu dan takut salah ketika ditunjuk guru untuk memaparkan hasil diskusinya.Rata-rata aktivitas siswa yang berkategori cukup dan belum memenuhi kriteria ketuntasan ada $56 \%$.Refleksi pada siklus I difokuskan pada berbagai masalah yang muncul pada pelaksanaan tindakan.Dari berbagai permasalahan yang muncul pada pelaksanaan tindakan siklus I maka perlu diadakan perbaikan untuk pelaksanaan tindakan di siklus II.

Sebelum melaksanakan tindakan, peneliti membuat berbagai perencanaan yaitu: Peneliti menyiapkan rencana pelaksanaan Mata pelajaran PKN Kelas V dengan Standar Kompetensi 3. Memahami berorganisasi. Kompetensi Dasar 3.1 Mendeskripsikan pengertian organisasi, Mempersiapkan sumber dan media pembelajaran berupa buku paket PKN, alat tulis, serta media, Mempersiapkan alat evaluasi berupa tes tertulis atau lembar soal dan lembar kerja siswa (LKS), Membuat lembar pengamatan untuk guru dalam melaksanakan pembelajaran, Membuat lembar pengamatan aktivitas siswa dalam mengikuti kegiatan pembelajaran.

Pelaksanaan tindakan siklus I pada hari Selasa, 21 dan 28 Februari 2017. Berdasarkan data hasil pelaksanaan pembelajaran siklus II, didapatkan bahwa hasil belajar siswa mengalami peningkatan jika dibandingkan dengan data siklus I. Dapat diketahui bahwa nilai terendah yang diperoleh siswa adalah 60 dan nilai tertinggi adalah 100. Yang mendapatkan nilai 100 sebanyak 2 siswa, yang mendapatkan nilai 90 sebanyak 4 siswa, yang mendapatkan nilai 80 sebanyak 11 siswa, yang mendapatkan nilai 70 sebanyak 7 siswa, yang mendapatkan nilai 60 sebanyak 1 siswa. Rata - rata 80, presentase ketuntasan $96 \%$. Disajikan diagram sebagai berikut.

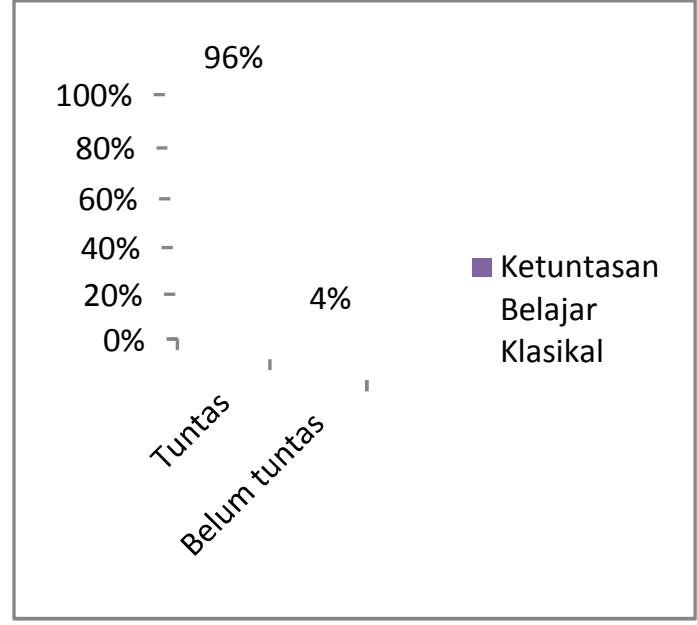

Gambar 4. Presentase Ketuntasan Belajar Klasikal Siklus II 
Hasil observasi berupa pengamatan terhadap aktivitas siswa antara lain: Kesiapan dan semangat siswa mengikuti proses pembelajaran (Emotional activities), Menanggapi apersepsi (Mental activities), Memperhatikan informasi yang disampaikan guru (Listening activities, Visual activities), Ketertiban pada saat pembentukan kelompok (Emotional activities), Mendiskusikan lembar pertanyaan yang diberikan guru (Mental activities, Motor activities, Writing activities), Kerjasama dalam kelompok.(Mental activities, Motor activities, Writing), Melaporkan hasil diskusi kelompok.(Oral activities), Ketertiban siswa ketika mendapatkan penghargaan dari guru (Emotional activities), Membuat kesimpulan diskusi/ pembelajaran bersama guru (Oral activities). Pada pelaksanaan tindakan siklus II yaitu pada Mata pelajaran PKN melalui Metode Pembelajaran Student Teams Achievment Divisions pada Kelas V SD Negeri 2 Sengonwetan

Dari data di atas dapat dilihat bahwa siswa yang belum tuntas dengan memperoleh nilai kategori cukup ada 2 siswa dengan presentase $8 \%$, siswa yang memperoleh nilai kategori baik ada 16 siswa dengan presentase $64 \%$,siswa yang memperoleh nilai kategori amat baik ada 7 siswadengan presentase $28 \%$. Rata-rata nilai aktivitas belajar siswa adalah 13 kategori baik dengan presentase nilai ketuntasan siklus II adalah $92 \%$.

Berdasarkan paparan diketahui bahwa aktivitas siswa pada siklus II telah terpenuhi secara maksimal.Hal ini dibuktikan dengan siswa yang sudah dapat melakukan pembagian kelompok secara cekatan dan tidak menimbulkan keributan. Keberanian siswa dalam menyampaikan hasil diskusi juga sudah baik, banyak siswa yang mulai berani memberikan pendapat terhadap hasil kerja kelompok lain. Rata-rata aktivitas siswa yang berkategori baik.Sehingga peneliti merasa tindakan sudah cukup dilakukan.

Hasil refleksi pada pelaksanaan tindakan siklus II adalah sebagai berikut: Aktivitas belajar siswa meningkatpesat dengan presentase ketuntasan $92 \%$, dan telah mencapai indikator keberhasilan. Hasil belajar yang diperoleh adalah nilai terendah 60 dan tertinggi 100 dengan rata - rata 80 dan persentase ketuntasan klasikal $96 \%$ dan telah mencapai indikator keberhasilan yaitu sekurangkurangnya ketuntasan klasikal 80\%.Untuk mengatasi ketuntasan klasikal yang belum mencapai 100\% telah dilaksanakan perbaikan bagi 1 siswa yang belum tuntas. Penelitian dihentikan pada siklus II.

\section{SIMPULAN}

Berdasarkan hasil penelitian mengenai peningkatan aktivitas dan hasil belajar PKN melalui model pembelajaran Student Teams Achievment Divisions (STAD) pada siswa kelas V SD Negeri 2 Sengonwetan, peneliti dapat menarik kesimpulan sebagai berikut: Hasil belajar siswa pada Mata pelajaran PKN dengan metode pembelajaran Student Teams Achievment Divisions (STAD) mengalami peningkatan pada setiap siklus. Hal itu dapat dilihat dari persentase ketuntasan Prasiklus48\%, meningkat menjadi $72 \%$ pada siklus I. Kemudian setelah dilakukan perbaikan, pada siklus II persentase ketuntasan kembali meningkat menjadi $96 \%$ dan telah memenuhi indikator keberhasilan yaitu sekurang-kurangnya $80 \%$. Aktivitas siswa pada penelitian ini mengalami peningkatan. Pada siklus I data hasil pengamatan siswa mendapatkan skor rata-rata 10 dengan kategori cukup dengan mencapai presentase ketuntasan $56 \%$. Pada siklus II aktivitas siswa meningkat dengan perolehan skor 13 dengan kategori baik dengan mencapai presentase ketuntasan $92 \%$. Dengan demikian dapat disimpulkan bahwa pemerolehan skor aktivitas siswa sudah memenuhi indikator keberhasilan. Jadi dapat disimpulkan, melalui model pembelajaran Student Teams Achievment Divisions (STAD) dapat meningkatkan aktivitas dan hasil belajar PKN pada siswa kelas V SD Negeri 2 Sengonwetan secara signifikan.

Berdasarkan simpulan mengenai peningkatan aktivitas dan hasil belajar PKN melalui model pembelajaran Student Teams Achievment Divisions (STAD) pada siswa kelas V SD Negeri 2 Sengonwetan di atas, maka disarankan: Guru yang akan menerapkan metode pembelajaran Student Teams Achievment Divisions (STAD) hendaknya dapat memaksimalkan pembelajaran yang dilakukan. Guru hendaknya lebih menciptakan pembelajaran yang meningkatkan tanggung jawab siswa dalam 
pemerolehan informasi untuk dirinya sendiri dan untuk kelompoknya sehingga guru dapat lebih meminimalisir aktivitas siswa yang mengganggu selama kegiatan pembelajaran berlangsung.

\section{DAFTAR RUJUKAN}

Al, D. M., Banjarmasin, H., Triyono, S., Brigjen, J., Hasan, H., \& Banjarmasin, B. (2017). PENDIDIKAN KEWARGANEGARAAN BERBASIS MULTIKULTURAL. Islamic Studies, 1(1).

Arikunto. (2010). Prosedur Penelitian. Rineka Cipta, Jakarta.

Depdiknas. (2003). Undang-Undang Republik Indonesia Nomor 20 Tahun 2003 Tentang Sistem Pendidikan Nasional. Undang-Undang Republik Indonesia, (1). https://doi.org/10.1017/CB09781107415324.004

Depdiknas. (2007). Undang-Undang Republik Indonesia Nomor 20 Tahun 2003 Tentang Sistem Pendidikan Nasional. Undang-Undang Republik Indonesia Nomor 20 Tahun 2003 Tentang Sistem Pendidikan Nasional, 1-33.

Hamdu, G. (2011). pengaruh belajar siswa terhadap prestasi. Penelitian Pendidikan, 12(1), 6.

Permana, E. P. (2016). PENERAPAN METODE PEMBELAJARAN KOOPERATIF NUMBERED HEADS TOGETHER (NHT) UNTUK MENINGKATKAN HASIL BELAJAR DAN BERPIKIR KRITIS SISWA PADA MATA PELAJARAN IPS SD. Jurnal Pendidikan Dasar Nusantara, 1(2), 49-58.

Uno, H. H. B. (2010). Model pembelajaran: menciptakan proses belajar mengajar yang kreatif dan efektif. Jakarta: Bumi Aksara. https://doi.org/10.1038/cddis.2011.1 